\title{
INFOGRAFIS ALASAN MENYONTEK DAN TIPE-TIPE PENYONTEK: PANDANGAN ETIKA MENGENAI PERILAKU MENYONTEK
}

\author{
Puri Kurniasih, Edo Galasro Limbong, Dian Handayani \\ Program Studi Desain Komunikasi Visual \\ Fakultas Bahasa dan Seni Universitas Indraprasta PGRI \\ Jl. Nangka 58 Tanjung Barat, Jakarta Selatan, 12530 \\ purikurniasih@gmail.com
}

\begin{abstract}
Abstrak
Menyontek atau penyontek berasal dari kata sontek. Perilaku menyontek merupakan hal yang sudah tidak asing lagi. Sejauh ini perilaku menyontek hanya diteliti berdasarkan data statistik dan konsep psikis, belum ada pandangan filosofis yang membedahnya. Artikel ini berusaha menjabarkan dan memberikan pandangan filsafat moral -atau yang lebih dikenal dengan etika- mengenai perilaku menyontek. Pandangan moral mengenai perilaku menyontek diperiksa ulang dari hasil penelitian-penelitian sebelumnya secara koherensi dan dirumuskan berdasarkan struktur kesadaran Sigmund Freud. Penelitian didasarkan pada pendekatan kualitatif dengan metode Focus Group Discussion (FGD) untuk proses perancangan infografis dan studi literatur untuk pengumpulan data. Penelitian ini menghasilkan dua buah infografis "Alasan Menyontek" dan "Tipe-Tipe Penyontek". Simpulan, penelitian ini melaju dari hasil abstraksi atas pemikiran filosofis mengenai perilaku menyontek dan mendarat menjadi hasil konkret berupa infografis untuk mengampanyekan gerakan "Setop Menyontek!"
\end{abstract}

Kata Kunci: perilaku menyontek, etika, infografis

\begin{abstract}
Absract
Cheating or cheater comes from the word of sontek. Cheating behavior is a familiar thing. So far cheating behavior has only been examined based on statistical data and psychological concepts, there is no philosophical view that dissects it. This article seeks to describe and give a moral philosophical view - or better known as ethics - about cheating behavior. A moral view of cheating behavior was re-examined from coherently results of studies before and formulated based on Sigmund Freud's consciousness structure. The research based on a qualitative approach with the Focus Group Discussion (FGD) method for infographic design process and literature study for data collection. This research produced two infographics, "The Reasons for Cheating" and "Types of Cheater". This research conclusion progressed from the results of abstraction on philosophical thinking about cheating behavior and landing into concrete results in the form of infographics to campaign the "Stop Cheating!" movement.
\end{abstract}

Keywords: cheating behavior, ethics, infographic

\section{PENDAHULUAN}

Fenomena perilaku menyontek sering terjadi di berbagai belahan negara, baik di Indonesia ataupun di negara-negara lain. Misalnya, di India pada tahun 2015 sempat dihebohkan dengan aksi puluhan bapak yang memanjat tembok sekolah kemudian 
memberikan kunci jawaban untuk membantu anaknya saat ujian. Hal ini membuat para guru kelabakan untuk mengatasinya. Selain itu, terdapat perbuatan menyontek yang tidak biasa terjadi di negara Kazakhstan yang mana seorang laki-laki menyamar jadi perempuan untuk menggantikan pacarnya dalam menyelesaikan ujian untuk masuk perguruan tinggi (lensaterkini.web.id, 2015). Ujian sebagai bentuk evaluasi hasil belajar ternyata menjadi wahana untuk perilaku menyontek. Di Indonesia, menyontek dilakukan oleh banyak kalangan, bukan hanya pelajar, bahkan hingga guru, dosen, dan kalangan non akademis. Hal tersebut karena menyontek dianggap biasa dan wajar.

Di Indonesia perilaku menyontek kerap kali terjadi terlebih bila memasuki masa ujian nasional mulai dari tingkat Sekolah Dasar hingga Sekolah Menengah Atas yang selalu dilaksanakan satu tahun sekali untuk menentukan kelulusan. Selain itu kasus menyontek yang telah terjadi di dunia perguruan tinggi pada tahun 2016 tepatnya dibulan Agustus yaitu didapati sebanyak 1.580 dosen dari 4.512 dosen dinyatakan tidak lulus karena nilainya rendah berdasarkan uji sertifikasi yang dilakukan oleh Kementerian Riset Teknologi dan Pendidikan Tinggi (Kemristekdikti). Sebagian besar para dosen menulis tentang deskripsi diri mereka dengan menyontek atau copy paste dari rekan dosen yang telah lulus sertifikasi (beritagar.id, 2015). Bergesernya makna dari hakikat belajar di masyarakat yang mana prestasi menjadi tujuan dari hasil pembelajaran, menjadikan banyak orang mencari cara alternatif yang instan untuk mendapatkan prestasi. Masyarakat tidak lagi memandang proses dari belajar itu sendiri, melainkan hasil konkret dari belajar berupa rangking, nilai yang tinggi, kelulusan, sampai keberhasilan untuk masuk ke sekolah atau perguruan tinggi favorit. Sehingga, menyontek dijadikan cara alternatif untuk mendapatkan semua itu.

Salah satu penyebab kebiasaan menyontek di Indonesia sudah menjadi hal yang biasa atau tidak tabu dan dianggap sebagai suatu kebiasaan yang wajar-wajar saja adalah karena tidak ada hukum yang jelas untuk mengaturnya yang mana hukum menyontek hanya diterapakan oleh pada diri guru dan dosen, tidak sepenuhnya dari pihak sekolah atau universitas (kabarindonesia.com, 2013). Tidak adanya hukum ketat yang mengatur serta mengurangi perbuatan menyontek membuat banyak orang beranggapan bahwa menyontek itu bukan perilaku negatif. Masih kurangnya pemahaman terhadap jenis-jenis menyontek, dan bahkan tidak sadar apa alasan yang membuat kita menyontek menjadi hal-hal yang perlu diinformasikan kembali, supaya lebih banyak lagi orang yang tahu dan sadar -sementara dampak dari menyontek sudah makin kentara dan kasat mata, karenasampai saat ini masih banyak murid, mahasiswa, dan bahkan para pengajar diberbagai jenjang pendidikan di Indonesia yang belum tahu bahwa ada beberapa perilaku saat mengerjakan ujian atau membuat tugas yang masuk dalam ketegori menyontek, kemungkinan banyak yang belum sadar bahwa menyontek itu salah, keliru, dan jahat, bahkan masih banyak yang tidak tahu apa sebab yang membuat seseorang menyontek. Itulah mengapa perlu adanya pemberian informasi mengenai perilaku menyontek.

Menyontek juga dapat dalam tiga kategori menurut Eric M. Anderman dan Tamera B. Murdock, yaitu memberikan atau menerima informasi, menggunakan materi yang dilarang atau membuat catatan, memanfaatkan kelemahan seseorang, prosedur atau proses untuk mendapatkan keuntungan dalam tugas akademik. Oleh karena itu, ketiga hal inilah yang biasanya dapat dijadikan sebagai langkah dasar seorang pelajar dimanapun untuk melakukan tindak kecurangan akademik, baik dalam skala kecil misalnya ulangan harian maupun skala besar yaitu ujian nasional (kompasiana.com, 2013). Bila melihat dari kategori tersebut, maka seseorang yang memberikan jawaban kepada rekannya saat ujian termasuk dalam jenis perbuatan menyontek dan perbuatan tersebut sangat jarang 
disadari oleh kaum pelajar. Sampai saat ini masih banyak murid, mahasiswa, dan bahkan para pengajar diberbagai jenjang pendidikan di Indonesia yang belum tahu bahwa ada beberapa perilaku saat mengerjakan ujian atau membuat tugas yang masuk dalam ketegori menyontek, kemungkinan banyak yang belum sadar bahwa menyontek itu salah, keliru, dan jahat, bahkan masih banyak yang tidak tahu apa sebab yang membuat seseorang menyontek.

Sejauh ini, perilaku menyontek lebih banyak dibahas pada ranah spikologis, seperti hasil penelitian pada skripsi beberapa mahasiswa Psikologi Universitas Indonesia. Sementara kebaruan dari penelitian ini, selain membahas perilaku menyontek secara lebih filosofis, juga memberikan luaran konkret yang dapat diakses oleh berbagai kalangan. Penelitian tidak akan lagi mencari data-data empiris seperti penelitian sebelumnya, melainkan lebih terkonsentrasi pada teori etika yang tepat untuk memecahkan konsepsi moral pada perilaku menyontek dan penyaringan hasil diskusi atas bentuk perancangan atau desain visual yang menarik dan bentuk komunikasi yang tepat sasaran.

\section{METODE}

Metode penelitian dapat diartikan sebagai seluruh nilai, asumsi-asumsi, etika serta norma yang menjadi aturan-aturan standar yang dapat digunakan dalam menafsirkan data penelitian yang ada, termasuk dapat digunakan untuk menilai kualitas hasil penelitian. Dalam penelitian ini menggunakan pendekatan kualitatif. Pendekatan kualitatif merupakan suatu penelitian yang tidak mengandalkan bukti berdasarkan kepada logika matematis, prinsip angka, atau statistik (Mulyana, 2006).

Bertolak dari pengetahuan umum pemikiran filsafat plato dapat disimpulkan bahwa tujuan hidup manusia adalah untuk mencapai eudaimonia (kebahagiaan). Kebahagiaan dapat dicapai melalui pembelajaran pengetahuan sejati. Pengetahuan yang sejati hanya ada di dalam dunia ide. Ide tertinggi adalah ide kebaikan (etika). Kebenaran didapatkan dari pengetahuan sejati (Bagus, 2000). Plato membagi teori kebenaran menjadi dua, yaitu teori korespondensi dan koherensi. Penelitian ini menggunakan teori koherensi sebagai metode. Teori Koherensi (Coherence Theory of Truth) Teori kebenaran koherensi adalah teori kebenaran yang didasarkan kepada kriteria koheren atau konsistensi. Suatu pernyataan disebut benar bila sesuai dengan jaringan komprehensif dari pernyataanpernyataan yang berhubungan secara logis (Santosa, n.d.). Dengan demikian, penelitian ini diawali dengan mengumpulkan pernyataan-pernyataan yang logis berdasarkan hasil penelitian sebelumnya, yaitu pernyataan-pernyataan dari hasil penelitian beberapa mahasiswa psikologi mengenai perilaku menyontek.

Materi infografis menggunakan beberapa buku etika dari Franz Magnis Suseno: Etika Dasar (1987), Etika Umum (1975), 13 Model Pendekatan Etika (1998), 12 Tokoh Etika Abad ke-20 (2000), dan buku karya K. Bertens (1993): Etika, khususnya pada bagian Etika dan Psikoanalisa Sigmund Freud untuk meninjau ulang perilaku menyontek supaya dapat merumuskan etika apa yang tepat menjernihkan permasalahan moral pada perilaku menyontek.

Etika merupakan salah satu cabang filsafat. Menurut K. Bertens, etika dimengerti sebagai filsafat moral. Etika berasal dari kata Yunani ethos yang dalam bentuk tunggal mempunyai arti: tempat tinggal yang biasa; padang rumput, kandang; kebiasaan, adat; akhlak, watak; perasaan, sikap cara berpikir. Dalam bentuk jamak (ta etha) artinya adalah: adat kebiasaan. Arti dalam bentuk jamak inilah yang menjadi latar belakang bagi terbentuknya istilah "etika" yang digunakan oleh Aristoteles untuk menunjukkan filsafat 
moral. Dengan demikian, secara etimologis etika dapat diartikan sebagai ilmu tentang apa yang biasa dilakukan atau ilmu tentang adat kebiasaan (Bertens, 1993). Sementara berdasarkan Kamus Besar Bahasa Indonesia, etika dijelaskan dengan membedakan tiga arti: 1. Ilmu tentang apa yang baik dan apa yang buruk dan tentang hak dan kewajiban moral; 2. Kumpulan asas atau nilai yang berkenaan dengan akhlak; 3. Nilai mengenai benar dan salah yang dianut suatu golongan atau masyarakat (Badan Pengembangan dan Pembinaan Bahasa, 2018)

Sifat dasar etika adalah sifat kritis. Etika bertugas untuk mempersoalkan normanorma yang dianggap berlaku. Diselidikinya apakah dasar suatu norma itu dan apa dasar itu membenarkan ketaatan yang dituntut oleh norma itu. Etika dapat mengantar orang kepada kemampuan untuk bersikap kritis dan rasional, untuk membentuk pendapatnya sendiri dan bertindak sesuai dengan apa yang dapat dipertangungjawabkannya sendiri. Etika menyanggupkan orang untuk mengambil sikap yang rasional terhadap semua norma, baik norma-norma tradisi maupun norma-norma lain. Sekaligus etika membantu manusia untuk menjadi lebih otonom. Otonomi manusia tidak terelak dalam kebebasan dari segala norma dan tidak sama dengan kesewenang-wenangan, melainkan tercapai dalam kebebasan untuk mengakui norma-norma yang diyakininya sendiri sebagai kewajibannya. Suatu pendapat moral dapat didekati dengan berbagai cara. Fenomena kesadaran moral yang otonom dan heteronom dari segi psikologi dapat mengikuti garis besar teori Sigmund Freud, karena kerangka susunan jiwa sebagaimana digambarkan olehnya, berguna untuk lebih mendalamai fenomena kesadaran moral (Suseno, 1975).

Etika adalah pemikiran sistematis tentang moralitas. Yang dihasilkan secara langsung bukan kebaikan, melainkan suatu pengertian yang lebih mendasar dan kritis. Etika pada hakikatnya mengamati realitas moral secara kritis. Etika tidak memberikan ajaran, melainkan memeriksa kebiasaan-kebiasaan, nilai-nilai, norma-norma dan pandangan-pandangan moral secara kritis. Etika menuntut pertanggungjawaban dan mau menyingkapkan kerancuan. Etika tidak membiarkan pendapat-pendapat moral begitu saja, melainan menuntut agar pendapat-pendapat moral yang dikemukakan dipertanggungjawabkan. Etika berusaha untuk menjernihkan permasalahan moral (Magnis Suseno, 1987).

Dalam meneliti nilai moral apa yang didapatkan dari perilaku menyontek, penulis tidak lagi menggunakan tata cara korespondesi dan pengumpulan data empiris (bahan mentah), melainkan dengan melakukan studi literatur secara koherensi mengumpulkan data yang sudah jadi dengan merumuskan ulang kesimpulan-kesimpulan yang dihasilkan oleh literatur-literatur tersebut.

Literatur yang dimaksud adalah beberapa skirpsi. Perilaku menyontek sudah menjadi objek yang cukup banyak dikaji di berbagai wilayah, terutama pada ranah psikologi dari mulai jurnal, artikel, buku, hingga tugas akhir atau skripsi. Namun, dari sekian banyak hasil kajian dan penelitian, kebanyakan berupa hasil teoritis dan masih sedikit menghasilkan luaran praktis. Penelitian sebelumnya lebih banyak berupa penelitian untuk Skripsi. Dengan demikian, Tim Peneliti menyortir skripsi-skripsi di Perpustakaan Universitas Indonesia yang meneliti dan membahas mengenai perilaku menyontek -ditulis oleh mahasiswa Fakultas Psikologi UI.

Skripsi-skripsi tersebut hanya memberikan luaran-luaran berupa data empiris hasil survei, diskusi, perhitungan reliabilitas skala, Pattern of Adaptive Learning Scales (PALS) dan Tennessee Self Concept Scales (TSCS) untuk menunjukkan data perilaku menyontek di berbagai kalangan, serta konsep imbauan dan penerapan religiusitas untuk mencegah tindak perilaku menyontek. Namun, tidak ada luaran konkret yang dapat 
langsung dilihat atau dibaca oleh siapapun yang pernah, akan, berniat, ataupun sudah tobat dari perilaku menyontek. Sebagus apapun hasil penemuan, kalau sekadar berbentuk skripsi hanya akan dibaca oleh kalangan tertentu saja. Dengan demikian, berangkat dari data-data yang sudah komrehensif dari 5 skripsi tersortir dan agar supaya dapat diakses oleh berbagai kalangan, selanjutnya Tim Peneliti melakukan perancangan visual untuk kampanye SETOP MENYONTEK!

Dalam perancangan infografis, penelitian ini menggunakan buku Jason Lankow dkk, berjudul "Infografis Kedasyatan Cara Bercerita Visual" infografis merupakan singkatan dari "grafis informasi". Sebagian orang menggunakan istilah ini untuk dapat mengartikan format unik yang telah digunakan secara luas untuk aplikasi ini, yang dicirikan dengan ilustrasi, tipografi besar, dan orientasi memanjang, vertikal yang menampilkan berbagai fakta (Lankow, Ritchie, \& Crooks, 2014).

Sejak manusia purba membuat lukisan di dinding gua sampai visualisasi data zaman modern, kita telah selalu memanfaatkan gambar sebagi cara untuk menampilkan informasi. Kemanjuran ini telah terbukti sejak Zaman Victoria, sebagaimana dibuktikan dengan infografis yang memperlihatkan penyebab-penyebab kematian di antara pasukan Inggris selama perang Krim. Dalam De Architectura, arsitek dan insinyur Romawi Vitruvius menyatakan ada tiga standar yang harus dipenuhi oleh semua struktur, yaitu: kekuatan, kegunaan, dan keindahan. Menurut Andrew Vande Moere dan Helen Purchase, standar-standar tersebut dapat serta harus diterapkan pada perancangan informasi dan berbagai aplikasi yang dimaksudkan untuk meraih tujuan tersebut. Selain itu mereka menyatakan bahwa sebuah visualisasi yang baik harus andal; artinya, rancangan harus sesuai untuk informasi yang digambarkannya. Visualisasi harus berguna, memungkinkan pemirsa memetik makna dari situ. Dan tentu saja, seperti semua desain atau rancangan, ia harus memiliki daya pikat estetis yang menarik perhatian orang dan menyuguhkan pengalaman visual yang menyenangkan (Lankow et al., 2014).

Menurut Jane Richie (Moleong, 2006), dari kajian tentang berbagai definisi penelitian kualitatif, dapat disintesiskan bahwa penelitian kualitatif adalah penelitian yang bermaksud untuk memahami fenomena tentang apa yang dialami oleh subjek penelitian seperti perilaku, persepsi, motivasi, tindakan, dan lain-lain, secara holistik dan dengan cara deskripsi dalam bentuk kata-kata dan bahasa. Kemudian untuk merancang infografis, metode penelitian yang dipergunakan adalah Focus Group Discussion (FGD).

FGD merupakan salah satu jenis penelitian survei. Sarantakos dalam (Ardial, 2014) menyatakan bahwa metode ini awalnya berkonsentrasi pada proses yang terjadi di dalam kelompok diskusi berlangsung, namun kemudian bergeser dengan penekanan pada isi diskusi. Menurut Birowo (2004: 126) dalam (Ardial, 2014) menjelaskan bahwa FGD digunakan oleh berbagai pihak yang menggali data secara mendalam melalui pemancing suatu isu atau topik tertentu yang telah dipersiapkan. Para partisipan dibantu seorang moderator mendiskusikan topik tersebut berdasar pertanyaan penuntun yang telah dirancang. Pada bidang ilmu komunikasi, FGD berfungsi untuk dapat memahami sikap dan perilaku khalayak berkaitan dengan pesan yang mereka peroleh. FGD menerapkan model komunikasi konvergen dalam metode ilmu komunikasi memiliki implikasi bahwa komunikasi merupakan suatu proses yang melibatkan partisipan-partisipan. Para partisipan melakukan pertukaran pesan secara dialogis dalam kerangka memperoleh pemahaman bersama atas situasi sosial mereka. Pada umumnya ciri-ciri FGD yang dapat dikenali yaitu: setiap kelompok diskusi terdiri dari enam hingga 12 partisipan, merupakan individu-individu yang terpilih untuk dapat mengikuti wawancara secara mendalam, diskusi berfokus pada suatu topik khusus yang difasilitasi seorang moderator. 
Dalam kaitan dengan tujuan penelitian merancang infografis sebagai media kampanye gerakan SETOP MENYONTEK! di kalangan pelajar, maka metode FGD dengan melibatkan mahasiswa DKV Universitas Indraprasta PGRI serta dosen yang pernah mengawas ujian diasumsikan sebagai metode yang tepat. Hal ini dengan asumsi bahwa dengan melibatkan partisipan-partisipan yang telah ditetapkan akan dapat menggali data mengenai perancangan infografis sebagai media kampanye gerakan SETOP MENYONTEK!

\section{HASIL DAN PEMBAHASAN}

Menyontek merupakan sebuah kata yang sudah tidak asing lagi untuk didengar terutama bagi pelajar dan mahasiswa. Menurut Kamus Besar Bahasa Indonesia (Badan Pengembangan dan Pembinaan Bahasa, 2018), menyontek berasal dari kata sontek yang berarti melanggar, menocoh, menggocoh yang artinya mengutip tulisan, dan lain sebagainya sebagaimana aslinya, menjiplak.

Banyaknya perilaku menyontek pada berbagai kalangan usia di Indonesia dan bahkan sudah dianggap biasa -dan menjadi kebiasaan kemudian- atau tidak tabu lagi menjadi hal yang banyak mendapat perhatian dari berbagai pihak ataupun instansi. Selain itu, tidak adanya hukum ketat yang mengatur serta mengurangi perbuatan menyontek dan masih kurangnya pemahaman terhadap jenis-jenis menyontek yang selama ini terjadi, sementara dampak dari menyontek sudah makin kentara dan kasat mata. Korupsi, kolusi, dan nepotisme adalah kejahatan yang lahir dari perilaku menyontek. Sementara zargon pemerintahan saat ini selain "kerja, kerja, dan kerja" adalah juga "revolusi mental". Mental bangsa ini dapat direvolusi salah satunya di bidang pendidikan adalah dengan menyetop kebiasaan menyontek. Oleh sebab itu, artikel ini memberikan urgensi terhadap kepentingan pemerintah dan masyarakat untuk menyetop kebiasaan menyontek.

\section{Perilaku Menyontek Berdasarkan Penelitian Psikologi}

Berikut adalah hasil sortir skripsi-skripsi di Perpustakaan Universitas Indonesia yang meneliti dan membahas mengenai perilaku menyontek -ditulis oleh mahasiswa Fakultas Psikologi UI, diantaranya:

1. Skripsi 1 (S2051)

Hubungan antara Konsep Diri dengan Sikap terhadap Tingkah Laku Menyontek di Kalangan Mahasiswa Universitas Indonesia, oleh Achmad Nusolahardo, 1988.

2. Skripsi 2 (S2446)

Efektivitas Jenis Imbauan terhadap Pencegahan Perilaku Menyontek, oleh Revo Multiko Putra, 1991.

3. Skripsi 3 (S2754)

Hubungan Motivasi Berprestasi dan Orientasi Achievement Goals dengan Perilaku Menyontek pada Siswa SMU, oleh Ratna Maulitai Rahayu, 1999.

4. Skripsi 4 (S56669)

Hubungan antara Konsep Diri dan Perilaku Menyontek Studi pada Siswa SMK Negeri 1 Palopo, oleh Dyah Utami Sulistianingtyas, 2014.

5. Skripsi 5 (S58499)

Hubungan antara Orientasi Religius (Intrinsik dan Ekstrinsik) dan Perilaku Menyontek pada Siswa SMA, oleh Nafilatul Falah, 2014.

Skripsi 1 menyimpulkan bahwa, ada hubungan korelasional antara konsep diri dengan sikap terhadap tingkah laku menyontek. Konsep diri yang dimiliki oleh seseorang 
dapat menjadi satu faktor yang ikut menentukan sikapnya terhadap tingkah laku menyontek. Konsep diri yang tinggi yang dimiliki seseorang memainkan peranan penting untuk menolak tingkah laku menyontek. Semakin rendah konsep diri seseorang, semakin menerima terhadap tingkah laku menyontek. Berdasarkan hasil survei, diskusi, dan perhitungan reliabilitas skala sikap, mahasiswa Universitas Indonesia menolak tingkah laku menyontek, ini mengindikasikan bahwa mahasiswa Universitas Indonesia memiliki konsep diri yang tinggi (Nusolahardo, 1988).

Skripsi 2 menyimpulkan bahwa, kehadiran imbauan selama proses tes klasikal yang bertujuan mencegah tampilnya perilaku menyontek- dapat mencegah tampilnya perilaku menyontek tersebut khususnya pada kelompok peserta dalam rentang usia 20-50 tahun, terlepas dari seperti jenis apa imbauannya. Kehadiran imbauan berperan efektif dalam mengurangi jumlah peserta yang menyontek. Berdasarkan pengolahan data, perilaku menyontek tidak berhubungan dengan usia subjek (Putra, 1991).

Pada skripsi 3, menyimpulkan bahwa ada hubungan yang signifikan antara motivasi berprestasi dengan perilaku menyontek; tidak ada hubungan yang signifikan antara achievement goal dengan perilaku menyontek; tidak ada hubungan yang signifikan antara performance goal dengan perilaku menyontek. Dengan demikian, semakin tinggi motivasi berprestasi siswa, maka akan semakin jarang dia melakukan perilaku menyontek. Individu dengan motivasi berprestasi yang tinggi akan lebih memilih bertanggungjawab secara pribadi pada hasil unjuk kerjanya, karena hanya dengan begitu mereka dapat merasa puas dalam melakukan sesuatu yang lebih baik. Dengan demikian, apabila mereka meyontek berarti kepuasan yang akan mereka dapatkan berkurang (Rahayu, 1999).

Skripsi 4 serupa dengan skripsi 1, hanya berbeda objek penelitian, tidak ada hal baru yang ditemukan, kesimpulannya sama bahwa ada hubungan signifikan antara konsep diri dengan perilaku menyontek. Bedanya, skripsi ini sudah menggunakan alat ukur Pattern of Adaptive Learning Scales (PALS) dan Tennessee Self Concept Scales (TSCS) (Sulistianingtyas, 2014).

Sementara skripsi 5 memberikan data yang cukup komprehensif soal menyontek. Skripsi 5 berpendapat bahwa pada dasarnya perilaku menyontek itu ada dua, yaitu serious cheating dengan social /collaborative cheating. Menyimpulkan bahwa tidak ada hubungan signifikan antara orientasi religius (intrinsik dan ekstrinsik) dengan perilaku menyontek pada siswa SMA, dengan mengontrol jenis sekolah (sekolah agama dan sekolah umum) serta jenis kelamin (laki-laki dan perempuan). Menyontek dapat dilakukan oleh siapa saja dan dimana saja. Perilaku ini ternyata dapat menjangkit siapa saja, bahkan untuk yang tercitra religius sekalipun. Skripsi 5 memberikan saran praktis agar siswa, orang tua, dan guru seharusnya lebih menyadari pentingnya meninggalkan perilaku menyontek karena berdampak negatif pada diri sendiri, orang lain, dan Indonesia. Mengurangi perilaku menyontek yang efektif adalah dengan menanamkan nilai-nilai religius pada siswa hingga taraf afektif, bukan hanya sekadar taraf kognitif. Misalnya, dengan cara menghapuskan ujian agama di sekolah agar siswa tidak mempelajari agama semata-mata untuk mendapatkan nilai. Namun, sekolah tetap perlu memberikan aspek penilaian sikap di sekolah terkait perilaku sehari-hari yang sesuai dengan nilai-nilai religius. Siswa juga perlu diwajibkan mengikuti kelompok mentoring keagamaan agar mereka dapat mempelajari nilai-nilai religius dengan cara yang lebih santai dan lebih terinternalisasi pada setiap siswa. Orang tua juga seharusnya menyadari pentingnya menjadi role model bagi anak-anaknya, dimana orang tua harus lebih menjaga perilaku yang ditunjukkan ketika berinteraksi dengan anak-anaknya. Dalam hal ini, orang 
tua adalah pihak yang paling dekat dengan anak sehingga perilaku yang ditunjukkan oleh anak kemungkinan adalah cerminan dari perilaku orangtuanya (Falah, 2014).

Berdasarkan hasil sortir dan analisis, kami merumuskan ulang menjadi ada 7 tipe penyontek. Perumusan ini lebih kepada pereduksian dari hasil penelitian-penelitian sebelumnya, Tim peneliti menggabungkan beberapa tipe yang sejenis menjadi satu tipe. Selain itu, perumusan ini didasarkan pada target khalayak pembaca pesan infografis tersebut, yaitu pelajar. Sehingga, istilah atau kata-kata dibuat sedemikian rupa sehingga familiar dan mudah dipahami oleh kalangan usia siswa maupun mahasiswa. Berikut tipetipe penyontek yang Tim Peneliti rumuskan:

1. Tipe Kode-Kodean

Ini adalah tipe penyontek yang menggunakan bagian tubuhnya (seperti jari tangan, kerlingan mata, suara) untuk mendapatkan ataupun memberikan jawaban dari soal pada saat ujian berlangsung.

2. Tipe Modus

Menggunakan alat dalam bentuk apapun untuk mendapatkan ataupun memberikan jawaban (baik manual maupun digital).

3. Tipe Kebakaran Jenggot

Menggunakan berbagai cara untuk mendapatkan jawaban karena terdesak oleh waktu, biasanya bersantai di awal dengan tidak mengerjakan soal ujian baru kemudian di detik-detik terakhir mulai bergerilya untuk mendapatkan jawaban.

4. Tipe Kriminal

Membeli soal atau jawaban.

5. Tipe Ekstrimis

Menyontek secara terang-terangan walaupun ada pengawas (sementara tipe lain biasanya dilakukan secara sembunyi-sembunyi).

6. Tipe Sohib

Saling member dan menerima jawaban demi pertemanan, bisa jadi tipe ini sebenarnya tidak ingin melakukan perbuatan menyontek, tapi demi pertemanan maka terpaksa menyontek.

7. Tipe Siaga

Ini adalah tipe yang sudah biasa menyontek; menyiapkan sontekan dalam bentuk apapun dimanapun sebelum ujian dimulai.

Sementara untuk faktor penyebab atau alasan mengapa seseorang menyontek, Tim Peneliti membaginya menjadi dua jenis, yaitu: faktor internal dan faktor eksternal (seperti hasil dari beberapa penelitian sebelumnya). Dibuat sedemikian rupa, sehingga istilah atau kata-kata menjadi sangat familiar dan mudah dipahami oleh kalangan pelajar baik siswa maupun mahasiswa. Berikut hasil perumusan mengenai alasan atau faktor mengapa seseorang menyontek:

1. Faktor Internal

Pada dasarnya, faktor internal ini merupakan faktor yang saling terkait satu sama lain, karena berasal dari dalam diri sendiri.

a. Gak Mampu

Perasaan tidak mampu, merupakan perasaan yang sangat umum dialami oleh para peserta ujian. Hal ini biasanya dikarenakan pembelajaran atau pemahaman yang kurang terhadap suatu pelajaran.

b. Gak Suka

Persoalan ini biasanya merupakan sentiment pribadi entah terhadap mata pelajaran atau mata kuliah ataupun pendidik (guru/dosen) yang terkait. Membuat, 
siswa atau mahasiswa menjadi acuh atau tidak peduli terhadap pelajaran atau mata kuliah tersebut, sehingga ketika ujian berlangsung mereka menyontek supaya asal lulus.

c. Asal Lulus

Faktor yang satu ini, bisa jadi karena merasa tidak mampu atau justru tidak suka sehingga berpikir "yang penting lulus" alias asal lulus, jangankan memikirkan nilai, faktor ini membuat pelajar berpikir mencari jalan cepat supaya lulus yaitu dengan menyontek.

d. Gak PeDe

Sesungguhnya, faktor ini adalah faktor utama mengapa seseorang merasa tidak mampu, yaitu karena merasa tidak percaya diri. Sebenarnya mampu, tapi karena perasaan tidak percaya diri sehingga dia merasa tidak mampu dan lebih percaya kepada kemampuan orang lain, itulah mengapa akhirnya ia menyontek.

e. Takut

Perasaan takut ini biasanya terbentuk dari luar, karena takut nilainya jelek, karena takut tidak naik kelas, karena takut dimarahi orang tua, karena takut diledek teman-teman, karena takut dihukum guru, dan rasa takut lainnya membuat seseorang menyontek supaya bisa lepas dari rasa takut tersebut.

f. Khawatir

Perasaan yang satu ini tidak jelas apa objeknya, biasanya ditandai dengan kegelisahan atau kegalauan, bukan takut terhadap sesuatu, tapi karena perasaan yang tidak jelas atau bisa disebut khawatir makan seseorang menyontek, biasanya ditandai dengan istilah "ya pengen aja", "ya nyontek aja", "semua orang nyontek jadi ya nyontek aja", semacam ikut-ikutan.

g. Malas

Ini adalah faktor yang ada pada setiap orang, namun tiap orang berbeda-beda dalam mengendalikan kemalasannya, biasanya seseorang menyontek karena tidak dapat mengendalikan rasa malas belajar.

h. Butuh Pujian

Faktor yang satu ini biasanya dialami oleh orang-orang yang biasanya berprestasi, biasa dipuji karena prestasinya namun ketika berada pada masa dimana merasa tidak mampu, tidak percaya diri, dan takut tidak lagi berprestasi, maka ia memutuskan menyontek untuk mempertahankan nilai atau prestasinya.

2. Faktor Eksternal

Ini adalah faktor dari luar yang dapat menimbukan faktor internal.

a. Susah

Karena soal yang susah, atau pelajaran yang susah dipahami biasanya menimbulkan perasaan-perasaan tidak mampu, tidak percaya diri, tidak suka, dan takut. Sehingga, memutuskan untuk menyontek.

b. Pertemanan

Ini adalah faktor yang cukup berbahaya, karena biasanya menimbulkan kekhawatiran. Selingkungan dengan para penyontek bisa membuat seseorang belajar untuk menyontek, berteman dengan penyontek biasanya membuat seseorang ingin 'membantu' atau juga ikut menyontek.

c. Keadaan

Soal yang susah, pelajaran yang susah dipahami, atau demi pertemanan adalah beberapa keadaan dari sekian banyak keadaan yang membuat orang ingin 
menyontek, bisa jadi tidak berada pada lingkungan penyontek tapi dalam keadaan tertentu seseorang menjadi penyontek.

d. Pengawas

Kekurangdisiplinan pengawas bisa menjadi penyebab mengapa seseorang menyontek, biasanya peserta ujian justru merasa punya kesempatan menyontek jika bertemu pengawas yang acuh, jika pengawas ketat biasanya para penyontek berpikir ulang untuk menyontek atau tidak, dengan demikian dalam logika para penyontek melahirkan pendapat bahwa ada pengawas yang asik dan tidak asik".

e. Tekanan

Soal yang terlalu banyak dan susah dengan waktu yang sangat sempit biasanya menjadi tekanan tersendiri bagi para peserta ujian, kondisi ini membuat mereka menyontek, padahal sebenarnya mereka mampu menyelesaikan soal-soal tersebut jikalau diberi waktu lebih.

f. Tuntutan

Faktor yang satu ini biasanya datang dari keluarga, apakah ibu atau ayah atau bahkan nenek kakek dan keluarga lainnya menuntut untuk siswa atau mahasiswa memiliki nilai bagus, dapat ranking, masuk ke sekolah atau perguruan tinggi favorit dan lain sebagainya menjadi alasan untuk menyontek.

Hasil penelitian-penelitian tersebut memberikan kesimpulan yang general bahwa perilaku menyontek adalah perilaku yang negatif, bahkan bisa dianggap tidak bermoral. Namun, tidak ada yang membahasnya langsung dari sudut pandang filsafat moral atau dikenal dengan istilah etika -semuanya ditelaah dengan kacamata psikologi -psikologi praktis. Dengan demikian, penelitian ini membahas perilaku menyontek dari beberapa teori pada etika untuk mendapatkan pemahaman yang lebih filosofis.

\section{Perilaku Menyontek Berdasarkan Struktur Kesadaran Freud}

Hasil penelitian berasal dari pembagian latar belakang fenomena kesadaran moral yang otonom dan heteronom dari sisi psikologi, karena kita adalah makhluk yang individual sekaligus sosial. Dijelaskan dalam infografis alasan menyontek bahwa ada faktor internal dan eksternal yang mempengaruhi orang untuk melakukan perbuatan sontek, artinya menyontek bukan hanya persoalan individual, melainkan sudah merupakan soal sosial. Dalam hal ini, Tim Peneliti meninjau secara kritis nilai moral dari teori Sigmund Freud mengenai kerangka susunan jiwa untuk lebih memahami fenomena dari tipe-tipe penyontek dan alasan internal maupun eksternal seseorang menyontek.

Freud membagi struktur kesadaran menjadi tiga, yaitu disebut dengan istilah "Id, Ego, dan Superego". Dirangkum dari berbagai sumber buku etika -yang menjadi referensi penelitian ini- yang membahas mengenai teori Freud, menjelaskan bahwa Id merupakan kondisi biologis manusia, memberikan dorongan terhadap kebutuhan dasariah. Kebutuhan itu sesuatu yang kita rasakan, yang muncul dari kita, tetapi tanpa kita sadari, seperti rasa lapar, haus, dingin, keinginan seks dan banyak hal lain yang menunjukkan adanya kebutuhan, ada dorongan, keinginan, naluri. Segala keinginan yang muncul dengan sendirinya. Dengan kata lain, Id adalah dorongan-dorongan, naluri-naluri, kebutuhan-kebutuhan, keinginan-keinginan yang keluar dari diri secara spontan merupakan suatu bagian dari kepribadian kita yang sifatnya prapersonal. Id adalah unsur pertama dalam kepribadian kita. Sementara unsur kedua adalah Superego, unsur kedua ini ditanamkan dari luar, seperti norma-norma yang diajarkan. Sehingga, dalam diri kita tertanam norma-norma dan tuntutan-tuntutan yang membuat kita harus menyesuaikan diri dengan hal tersebut. Unsur ketiga dalam kepribadian kita adalah si Aku kita sendiri yang 
selalu berhadapan dengan unsur-unsur Id dan Superego. Egolah yang mengambil sikap terhadap kecondongan, keinginan, dan dorongan-dorongan spontan serta terhadap tuntutan-tuntutan superego. Egolah yang berfungsi menangkap dan mengetahui realita, mencari pengalaman di sekeliling. Ego adalah unsur kita yang aktif, yang menentukan (Suseno, 1975).

Dalam perilaku menyontek, kita dapat melihat bahwa yang terjadi adalah benturan antara Ego dan Superego. Kita menjadi penyontek atau tidak itu adalah pilihan Ego kita. Persoalannya justru ada pada Superego, ketika norma-norma disekeliling kita mengajarkan bahwa menyontek itu adalah perbuatan jahat, dan tertanam dalam Superego untuk tidak melakukan hal tersebut, maka kemudian Ego akan berperan untuk mengikuti Superego atau sebaliknya. Dalam norma di masyarakat, merepresi Id jauh lebih mudah bagi Ego, ketimbang harus berbenturan dengan Superego. Demikian karena, biasanya norma-norma yang ditanamkan itu berbeda-beda mengenai sesuatu yang dianggap baik. Di satu lingkungan menyontek itu perbuatan yang haram dilakukan, tapi di lain lingkungan bisa jadi menyontek itu cara alternatif yang sah-sah saja dilakukan. Kondisi ini yang bisa membuat Ego kita bingung. Dengan demikian, Tim Peneliti berusaha menjernihkan kebingungan tersebut dengan mengangkat perilaku menyontek sebagai perbuatan yang negatif dan menginformasikan tipe-tipe apa saja yang masuk dalam perilaku menyontek, serta mengajak untuk melakukan reflesi diri mengenai apa alasan yang membuat kita menyontek melalui infografis.

\section{Perilaku Menyontek dalam Perancangan Infografis}

Tim Peneliti mengkaji ulang dan merumuskan hasil-hasil penelitian sebelumnya sebagai bahan data literatur supaya dapat membuat solusi rancangan infografis yang tepat. Kemudian, hasil rancangan sementara dilempar ke FGD untuk mendapatkan opini yang dapat dipertimbangkan bagi perbaikan rancangan infografis.

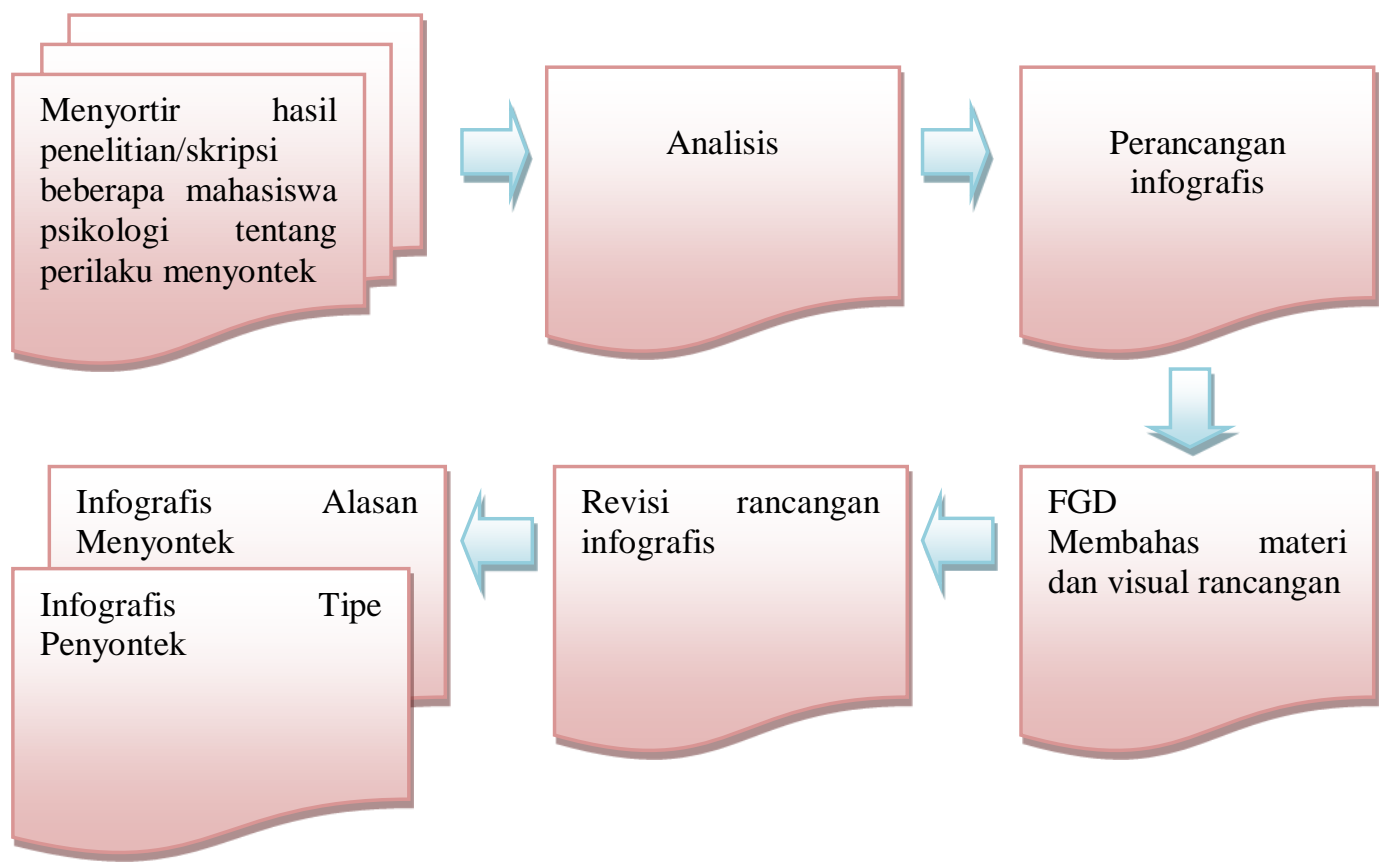


Bertolak dari beberapa penelitian mengenai perilaku menyontek dengan dasar analisis psikologi, Tim Peneliti mendapati bahwa, persoalan mendasar pada perilaku menyontek bukan lagi pada apa dampak menyontek ataupun apakah menyontek itu merupakan perilaku yang benar atau salah, cara yang tepat atau keliru, sikap yang baik atau jahat, jujur atau bohong, tindakan sportif atau curang. Semua hasil penelitian, menunjukkan bahwa jelas menyontek itu berdampak sangat buruk di masa depan, lahirnya para koruptor merupakah salah satu dampak negatif yang kentara dari perilaku menyontek. semua hasil penelitian juga menunjukkan bahwa jelas menyontek itu adalah perilaku yang salah, cara yang keliru, sikap jahat, bohong, dan tindakan yang curang untuk mendapatkan sesuatu. Sehingga, sudah jelas, menyontek merupakan salah satu sikap yang tidak bermoral.

Penelitian-penelitian berbasis psikologi tersebut lebih cenderung menyoroti mengenai mengapa seseorang melakukan perbuatan menyontek dan jenis-jenis atau tipetipe penyontek -perilaku seperti apa yang masuk dalam kategori menyontek. Nampak, masyarakat atau bahkan lebih spesifik masyarakat di dunia akademis pun belum tahu pasti apakah ada sikapnya ketika mengerjakan soal ujian atau mengerjakan tugas masuk ke dalam kategori menyontek. Bahkan, masih banyak dari kita yang tidak tahu apa alasan kita melakukan perbuatan menyontek tersebut. Dengan demikian, Tim Peneliti setuju dengan hasil penelitian-penelitian berbasis psikologi tersebut. Sehingga, Tim Peneliti memutuskan untuk merealisasikan hasil penelitian-penelitian tersebut menjadi sebuah infografis yang kemudian dapat disosialisasikan ke lebih banyak lagi orang selain orangorang yang berada di kalangan akademis -masyarakat luas.

Berdasarkan hasil penelitian tersebut diatas, akhirnya Tim Peneliti mengeksekusi perumusan menjadi sebuah infografis Tipe-Tipe Penyontek dan Alasan Menyontek sebagai sebuah perancangan visual dalam rangka kampanye gerakan setop menyontek di kalangan pelajar. Setelah mendapatkan rumusan tersebut, Tim Peneliti memvisualisasikannya menjadi sebuah infografis yang menarik untuk kalangan pelajar. Menggunakan warna-warna pastel dan ikon-ikon yang menarik terancanglah infografis sebagai berikut:

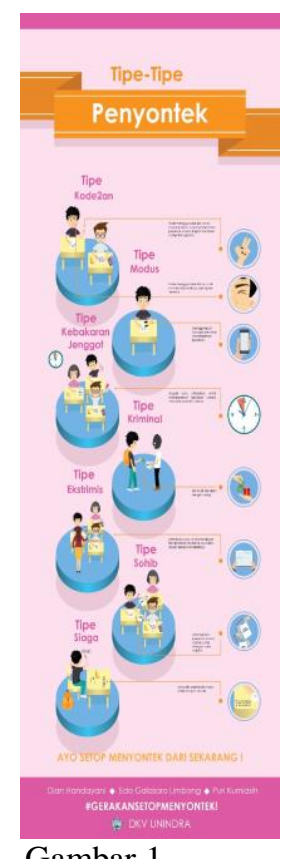

Gambar 1.

Tipe-Tipe Penyontek (1)

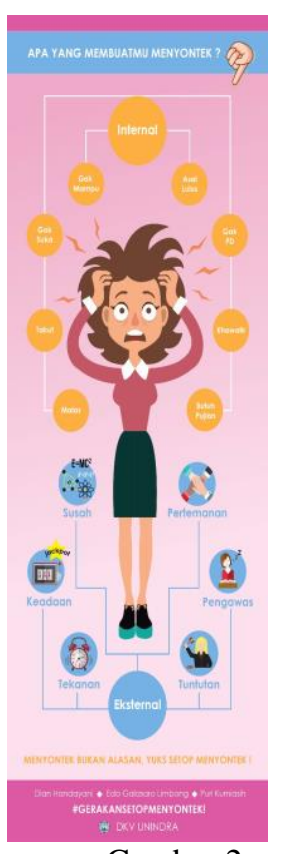

Gambar 2.

Alasan Menyontek (1) 
Rancangan sementara tersebut diatas (Gambar 1 dan 2) didiskusikan untuk kemudian direvisi agar mendapatkan rancangan yang baik. Forum Group Discussion dilakukan di Universitas Indraprasta PGRI pada beberapa mahasiswa DKV. Berdasarkan hasil FGD tersebut, banyak masukan berupa revisi untuk merubah ikon, jenis tulisan, dan warna. Berdasarkan pertimbangan Tim Peneliti, beberapa opini yang sekiranya bisa mempercantik infografis kemudian diaplikasikan untuk menjadi revisi.

Insight yang didapat dari literatur dan wawancara mendalam disepakati bahwa icon-icon yang digunakan mengarah kepada karakter usia pelajar baik untuk laki-laki maupun perempuan. Penggunaan warna dan karakter huruf (tipografi) juga disepakati warna - warna yang mengarah kepada usia remaja, penggunaan bahasa mengarah kepada bahasa yang sering dilapalkan sehari-hari oleh usia remaja.

1. Icon karakter tokoh yang digunakan

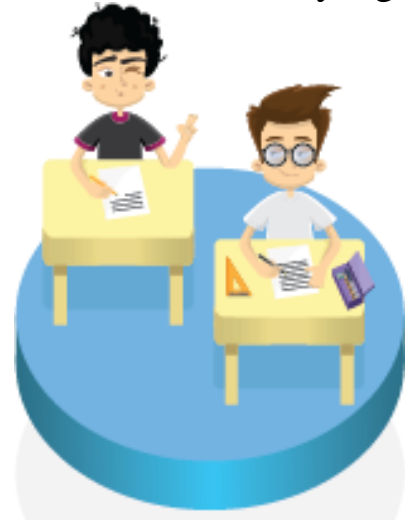

2. Penggunaan Warna yang digunakan

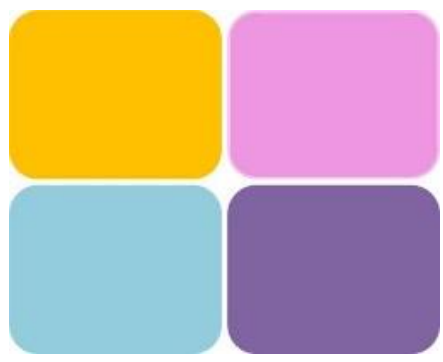

3. Icon -icon yang digunakan dalam pelengkap informasi

Makna
adajar yang berani menyontek walaupun
ada ujian di hadapan mereka



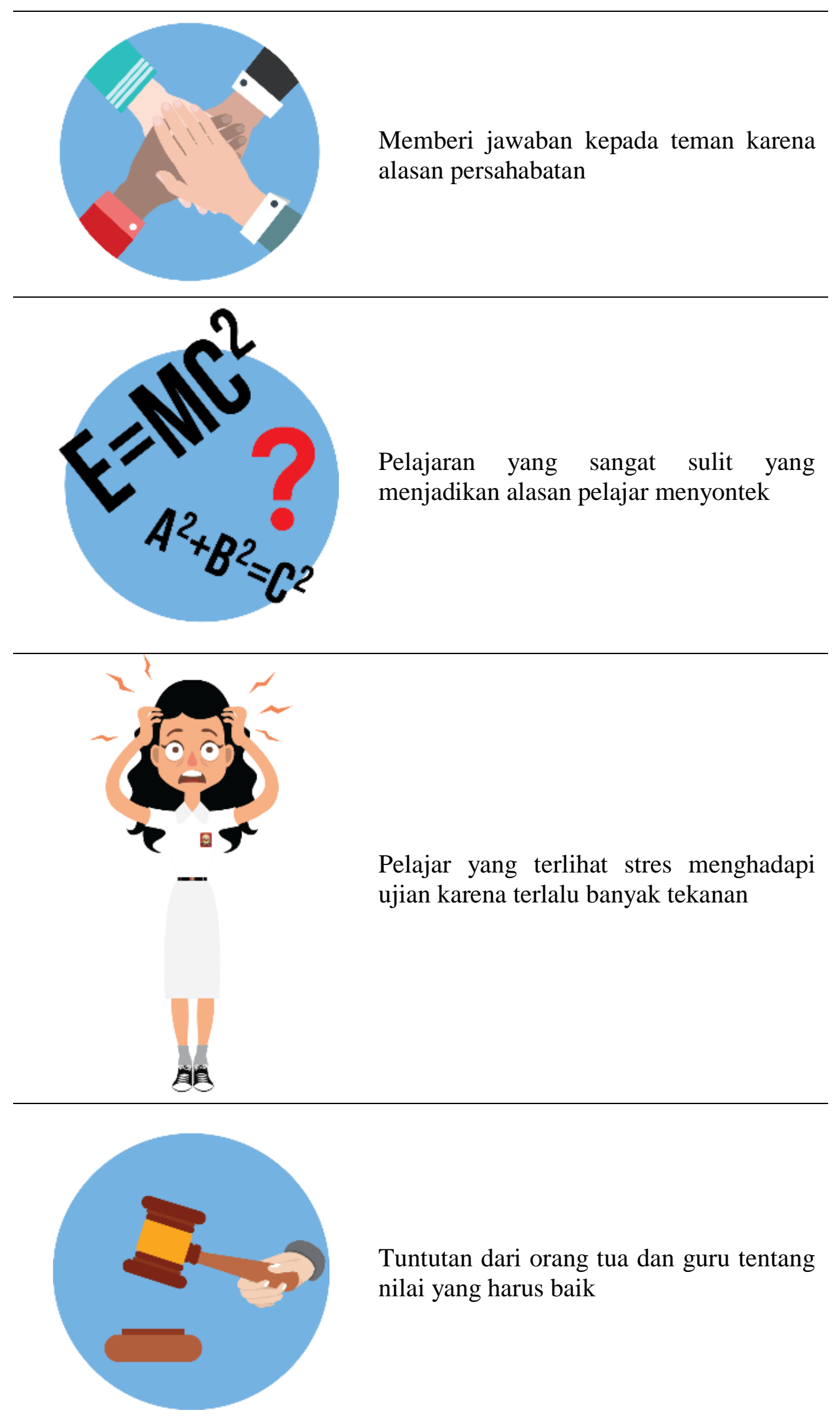

Tuntutan dari orang tua dan guru tentang nilai yang harus baik 
Berikut rancangan hasil revisi dari FGD:

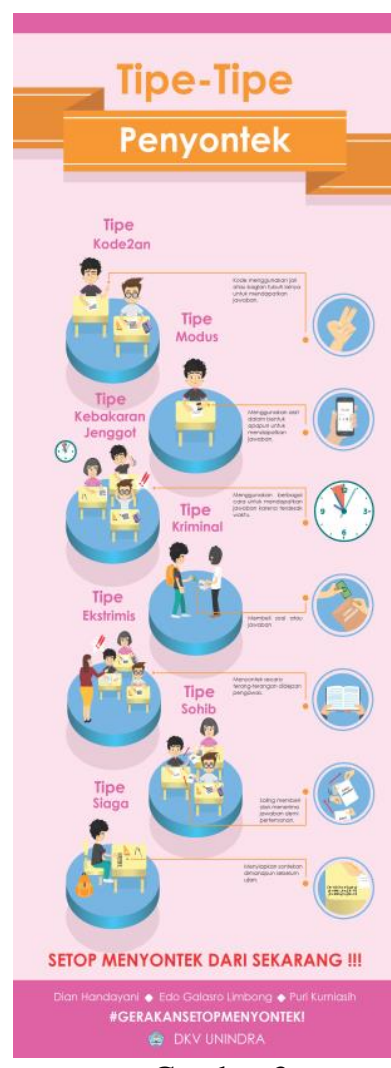

Gambar 3

Tipe-Tipe Penyontek (2)

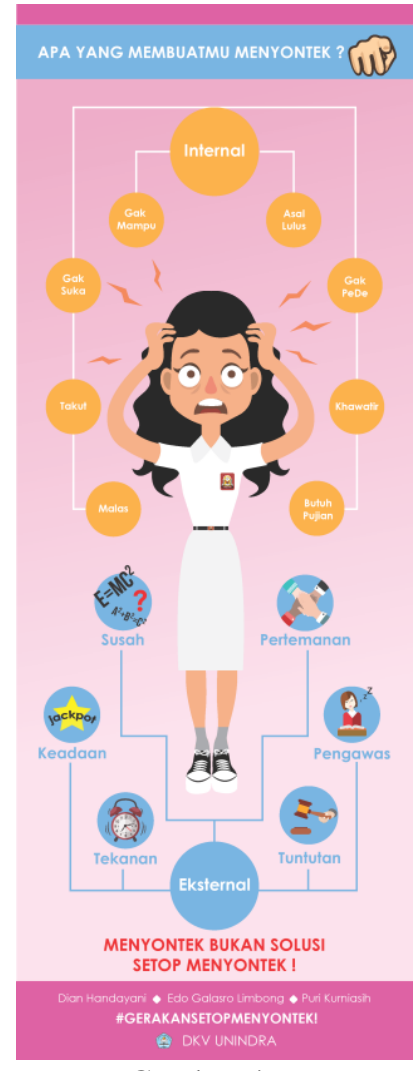

Gambar 4.

Alasan Menyontek (2)

Tipe-tipe penyontek semakin dewasa semakin beragam dan canggih. Pada dasarnya meniru adalah sifat alamiah manusia, ketika kita mengakui bahwa kita meniru itu dari mana atau dari siapa maka itu menjadi sesuatu yang sah, karena tidak ada hal yang benarbenar murni hasil kita sendiri, sejak lahir kita sudah dihadapkan pada kehidupan yang kompleks, kita tumbuh dan berkembang dari meniru segala sesuatu di sekitar kita, tentunya dengan bantuan orang tua/wali. Artinya, meniru itu sebenarnya sah, karena manusiawi atau kondisi natural manusia. Namun, meniru menjadi tidak sah atau dianggap keliru ketika meniru itu digunakan untuk kepentingan diri sendiri dengan sifat merugikan. Menyontek adalah bagian dari meniru yang tidak sah, karena jelas merugikan diri sendiri maupun orang lain dan bukan kondisi natural, melainkan sudah ada kepentingan tertentu.

\section{CONCLUSION}

Sudah banyak literatur yang meneliti mengenai perilaku menyontek, dari banyak literatur, disepakati bahwa jelas menyontek itu adalah perilaku menyimpang dari proses belajar. Dengan demikian, pada akhirnya untuk menanggulangi kondisi ini, kita tidak hanya butuh literatur sebagai bahan bacaan, namun juga bentuk visual yang lebih mudah dipahami dan menarik dalam rangka mengampanyekan gerakan setop menyontek di kalangan pelajar khususnya. 
Infografis adalah media yang mudah dipahami dan menarik para audiens, bukan hanya sistematis dan tertata, tapi ikon-ikon visual akan lebih mudah 'dibaca' oleh pikiran kita ketimbang kata-kata semata.

Etika merupakan salah satu bidang studi yang sebenarnya cukup berat walaupun bersifat praktis. Itulah mengapa, perlu membungkusnya dengan media yang mudah dipahami, supaya nilai praktisnya bisa langsung diterapkan. Kita tidak perlu lagi memberikan bacaan ataupun ceramah filsafat moral yang penuh dengan teori dan argumen untuk menyampaikan suatu pesan filosofis, karena pada penelitian ini etika dibungkus ke dalam sebuah media visual yang menarik.

Perilaku menyontek lebih banyak diteliti oleh bidang psikologi, sementara penelitian ini lebih dalam masuk ke bidang filsafat moral. Seharusnya banyak bidang lain juga melakukan penelitian untuk menanggulangi perilaku menyontek, supaya dapat banyak sudut pandang dan solusi dari berbagai bidang.

\section{REFERENCES}

Ardial. (2014). Paradigma dan Model Penelitian Komunikasi. Jakarta: Bumi Aksara.

Badan Pengembangan dan Pembinaan Bahasa, K. (2018). Kamus Besar Bahasa Indonesia (KBBI): Kamus versi online/daring (dalam jaringan).

Bagus, L. (2000). Kamus Filsafat. Jakarta: Gramedia.

beritagar.id. (2015). Ribuan Dosen Tak Lulus Uji Sertifikasi Karena Menyontek. Retrieved September 7, 2016, from https://beritagar.id/artikel/berita/ribuan-dosentak-lulus-uji-sertifikasi-karena-menyontek

Bertens, K. (1993). Etika. Jakarta: PT Gramedia Pustaka Utama.

Falah, N. (2014). Hubungan antara Orientasi Religius (Intrinsik dan Ekstrinsik) dan Perilaku Menyontek pada Siswa SMA. Universitas Indonesia.

kabarindonesia.com. (2013). Budaya Menyontek di Indonesia. Retrieved September 7, 2016, from http://www.kabarindonesia.com/berita.php?pil=12\&jd=Budaya+Menyontek+di+I ndonesia\&dn=20131227201117

kompasiana.com. (2013). Korupsi Kecil Itu Bernama Menyontek. Retrieved September 7, 2017, from http://www.kompasiana.com/elis.nvs/korupsi-kecil-itu-bernamamenyontek_552e2e726ea8349d178b45ac

Lankow, J., Ritchie, J., \& Crooks, R. (2014). Infografis Kedasyatan Cara Bercerita Visual. Jakarta: PT Gramedia Pustaka Utama.

lensaterkini.web.id. (2015). Aksi Mencontek Pelajar Paling Parah. Retrieved September 7, 2017, from http://www.lensaterkini.web.id/2015/10/5-aksi-mencontek-pelajarpaling-parah.html

Magnis Suseno, F. (1987). Etika Dasar. Yogyakarta: Kanisius.

Moleong, L. J. (2006). Metode Penelitian Kualitatif (Revisi). Bandung: PT Remaja Rosdakarya.

Mulyana, D. (2006). Ilmu Komunikasi Suatu Komunikasi (Cetakan Ke). Bandung: PT Remaja Rosdakarya. 
Nusolahardo, A. (1988). Hubungan antara Konsep Diri dengan Sikap terhadap Tingkah Laku Menyontek di Kalangan Universitas Indonesia. Universitas Indonesia.

Putra, R. M. (1991). Efektivitas Jenis Imbauan terhadap Pencegahan Perilaku Menyontek. Jakarta: Universitas Indonesia. Universitas Indonesia.

Rahayu, R. M. (1999). Hubungan Motivasi Berprestasi dan Orientasi Achievement Goals dengan Perilaku Menyontek pada Siswa SMU. Universitas Indonesia.

Santosa, B. (n.d.). Teori-teori Kebenaran: Korespondensi, Koherensi, Pragmatik, Struktural Paradigmatik, dan Performatik. Retrieved September 7, 2017, from https://www.kompasiana.com/boedis2/550f14b2a33311bb2dba84c7/teoriteorikebenaran-korespondensi-koherensi-pragmatik-struktural-paradigmatik-danperformatik

Sulistianingtyas, D. U. (2014). Hubungan antara Konsep Diri dan Perilaku Menyontek Studi pada Siswa SMK Negeri 1 Palopo. Universitas Indonesia.

Suseno, F. M. (1975). Etika Umum: Masalah - masalah Pokok Filsafat Moral. Yogyakarta: Yayasan Kanisius. 